\title{
Procoagulant Proteins from Snake Venoms
}

\author{
R. Manjunatha Kini ${ }^{a, c}$ Veena S. Rao ${ }^{a}$ Jeremiah S. Joseph ${ }^{b}$ \\ aDepartment of Biological Sciences, Faculty of Science, b ${ }^{b}$ Department of Biochemistry, \\ Faculty of Medicine, National University of Singapore, Singapore; \\ 'Department of Biochemistry and Molecular Biophysics, Medical College of Virginia, \\ Virginia Commonwealth University, Richmond, Va., USA
}

\section{Key Words}

Blood coagulation - Clotting cascade .

Venom proteinase

\begin{abstract}
Several procoagulant proteins from snake venoms have been isolated and characterized. They are either serine proteinases or metalloproteinases, which activate specific zymogens of coagulation factors and initiate the coagulation cascade. These procoagulant proteins are useful in treating various thrombotic and hemostatic conditions and contribute to our understanding of molecular details in the activation of specific coagulation factors. Recent studies have shown that the prothrombin activators with serine proteinase activity are structurally and functionally similar to mammalian coagulation factors. Their structural studies should provide
\end{abstract}

\begin{tabular}{ll}
\hline KARGER & ( 2002 S. Karger AG, Basel \\
Fax +41 61 306 1234 & 0301-0147/01/0316-0218\$17.50/0 \\
$\begin{array}{l}\text { E-Mail karger@karger.ch } \\
\text { www.karger.com }\end{array}$ & $\begin{array}{l}\text { Accessible online at: } \\
\text { www.karger.com/journals/hae }\end{array}$
\end{tabular}

us insight into prothrombinase complex formation. Here, we present an overview of snake venom procoagulant factors.

Copyright @ 2002 S. Karger AG, Basel

\section{Introduction}

Snake venoms are rich sources of pharmacologically active proteins and peptides. These toxins interfere in several vital physiologic functions; some act as agonists and behave similarly to a natural ligand or activator of a specific step, whereas others act as antagonists and interfere in the function of a natural ligand or activator. In general, the toxins exhibit high specificity and have evolved to attack the specific, and most likely, key step in the physiologic pathway. Thus, they affect various physiologic functions with high specificity and high potency. Therefore, snake ven-

\footnotetext{
R. Manjunatha Kini

Department of Biological Sciences, Faculty of Science

Block S2, Room 04-11, 14 Science Drive

National University of Singapore, Singapore 117543

Tel. +65 874 5235, Fax +65 779 2486, E-Mail dbskinim@nus.edu.sg
} 
om toxins provide several highly specific 'tools', which are useful in deciphering molecular details in various physiological processes. Some of these toxins are also useful in developing prototypes of therapeutic agents. Further, the study of toxins helps in developing protective measures to counter mortality and morbidity associated with snake envenomation.

The circulation of blood is essential for life and the integrity of the process is crucial for the survival of the organism. The integrity of this closed system is strictly regulated by the interplay of platelet aggregation, blood coagulation and vasoconstriction. These processes are intertwined and synergistic, and occur almost simultaneously to prevent blood loss from the injured vessel. Several snake venoms and their toxins have evolved to interfere in the mechanism of thrombosis and hemostasis. Some of these toxins affect platelet aggregation [1-4], whereas others affect blood coagulation [5-7]. In this review, we will describe structural and functional properties of procoagulant toxins.

\section{Procoagulant Proteins from Snake Venom}

Procoagulant venoms contain components that hasten clot formation. All the procoagulants characterized to date are proteinases; they activate a zymogen of specific coagulation factors in the coagulation cascade. Some venom proteinases also activate the protein cofactor, factor V. For example, Russell's viper (Daboia russelli) venom (RVV-V) and thrombocytin (Bothrops atrox) activate factor $\mathrm{V}$, the cofactor in the prothrombinase complex [reviewed in ref. 8 and 9].

\section{Factor VII Activation}

So far, snake venom proteins that specifically activate only factor VII are not known. However, oscutarin, a group $\mathrm{C}$ prothrombin activator (see below) from Oxyuranus scutellatus venom activates factor VII [10]. Gel electrophoresis analysis of the cleavage products indicated that activation occurred at a site similar to the natural cleavage site. The activation of factor VII, similar to that of prothrombin, was greatly potentiated by $\mathrm{Ca}^{2+}$ ions and phospholipids, and was not dependent upon the presence of its factor Va-like subunit [10]. The structural details of oscutarin and related proteins are given below.

\section{Factor X Activation}

Venoms from Viperidae, Crotalidae and Elapidae contain a variety of proteinases capable of activating factor $\mathrm{X}$ [for reviews, see ref. 11 and 12]. They are either metalloproteinases or serine proteinases. The factor $\mathrm{X}$ activator from RVV-X, first purified by Williams and Esnouf [13], is a metalloproteinase $\left(93 \mathrm{~K}_{\mathrm{d}}\right.$ glycoprotein) with a heavy chain (catalytic subunit) and two distinct light chains [14]. The heavy chain (427 residues) consists of a metalloproteinase, a disintegrin and a cysteine-rich domain [15]. The light chains are homologous to C-type lectins, particularly to factor IX/X-binding protein from Trimeresurus flavoviridis venom [16]. They act as regulatory subunits and recognize the $\mathrm{Ca}^{2+}$-bound conformation of the Gla domain of factor $\mathrm{X}$ [11]. This structure of RVV-X is very similar to that of the prothrombin activator, carinactivase-1, from Echis carinatus leukogaster (see below). RVV-X specifically cleaves the $\operatorname{Arg}_{52}-$ $\mathrm{Ile}_{53}$ bond in the heavy chain of factor $\mathrm{X}$, and it requires $\mathrm{Ca}^{2+}$ ions at millimolar concentrations for optimal activity. RVV-X is unable to

Haemostasis 2001;31:218-224 
activate factor $\mathrm{X}$ bound to negatively charged phospholipid bilayers; hence, it can be used to determine the binding of factor $\mathrm{X}$ to phospholipid vesicles [17]. Other metalloproteinase factor $\mathrm{X}$ activators from $B$. atrox and Cerastes cerastes venoms have structures similar to RVV-X [11]. Hence, they probably have similar catalytic mechanisms.

A few serine proteinases that activate factor $\mathrm{X}$ have also been isolated from the venoms of Ophiophagus hannah, Bungarus fasciatus, $C$. cerastes and $C$. vipera [11]. We have also isolated a serine proteinase factor $\mathrm{X}$ activator from the venom of the Malayan krait, Bungarus candidus [Joseph and Kini, unpubl. results]. However, currently no structural details are available on any of these proteins.

\section{Prothrombin Activators}

A large number of snake species contain prothrombin activators in their venoms [for an inventory, see ref. 18 and for reviews, see ref. 19-21]. Based on their structural properties, functional characteristics and cofactor requirements, they have been categorized into four groups [19, 22-23]. For a recent review on prothrombin activators, [see ref. 24].

\section{Group A Prothrombin Activators}

These metalloproteinases efficiently activate prothrombin without the requirement of any cofactors, such as $\mathrm{Ca}^{2+}$ ions, phospholipids or factor Va [19]. They are widely distributed in many kinds of viper venoms. The best-known example is ecarin, from the venom of the saw-scale viper E. carinatus [25]. The sequence of this protein was deduced from the sequences of cDNA clones [26]. The mature protein is a metalloproteinase with 426 amino acids and shares $64 \%$ identity with the heavy chain of RVV-X. It consists of three domains: a metalloproteinase, disintegrin and a cysteine-rich domain. It is a highly efficient enzyme with a low $\mathrm{K}_{\mathrm{m}}$ for prothrombin and a high $\mathrm{K}_{\text {cat }}$ [21]. It cleaves the $\mathrm{Arg}_{320}-\mathrm{Ile}_{321}$ bond in prothrombin and produces meizothrombin, which is converted to $\alpha$-thrombin by autolysis. Ecarin also activates descarboxyprothrombin that accumulates in plasma during warfarin therapy. Other prothrombin activators in this class $[18,19]$, for example those isolated from the Bothrops species, also have similar properties [21].

\section{Group B Prothrombin Activators}

These are $\mathrm{Ca}^{2+}$-dependent prothrombin activators, such as carinactivase-1 [23] and multiactivase [27] from E. carinatus leukogaster and E. multisquamatus venom, respectively. They consist of two subunits held noncovalently: a $62 \mathrm{~K}_{\mathrm{d}}$ metalloproteinase and a $25 \mathrm{~K}_{\mathrm{d}}$ C-type lectin-like disulfide-liked dimer. In contrast to the group A activators, carinactivase-1 requires millimolar concentrations of $\mathrm{Ca}^{2+}$ for activity; it has virtually no activity in the absence of $\mathrm{Ca}^{2+}$. Also, unlike ecarin, it does not activate prothrombin derivatives in which $\mathrm{Ca}^{2+}$-binding has been perturbed: prethrombin-1 and descarboxyprothrombin. This property is used to develop a chromogenic assay for normal prothrombin in the plasma of warfarin-treated individuals [28]. The metalloproteinase catalytic subunit taken in isolation does not require $\mathrm{Ca}^{2+}$ for activity and its reconstitution with the C-type lectinrelated subunit restores $\mathrm{Ca}^{2+}$ dependence. They recognize the $\mathrm{Ca}^{2+}$-bound conformation of the Gla domain in prothrombin via the $25 \mathrm{~K}_{\mathrm{d}}$ regulatory subunit.

\section{Group C Activators}

These are serine proteinases found apparently exclusively in the venoms of Australian elapids $[18,19]$, and they require only $\mathrm{Ca}^{2+}$ ions and negatively charged phospholipids, but not factor Va, for maximal activity. They 
have been purified and characterized from O. scutellatus [29-31] and Pseudonaja textilis venoms [32] [Rao and Kini, unpubl. obs.]. The native activators have a molecular mass of approximately $300 \mathrm{~K}_{d}$ and consist of a factor Xa-like catalytic subunit $\left(60 \mathrm{~K}_{\mathrm{d}}\right)$ and a factor Va-like cofactor subunit (approximately $200 \mathrm{~K}_{\mathrm{d}}$ ). The two chains of the factor Xa-like catalytic subunit are linked by disulfide bonds, whereas the two chains of the factor Va-like cofactor are held together by noncovalent interactions. The catalytic subunit, similar to factor $\mathrm{Xa}$, has weak catalytic activity in isolation, which is greatly stimulated by the presence of the factor Va-like subunit. Bovine factor Va can also substitute for the cofactor subunit of the enzyme [31, 32] [Rao and Kini, unpubl. obs.]. These activators cleave at both $\operatorname{Arg}_{271}-\mathrm{Thr}_{272}$ and $\mathrm{Arg}_{320}-\mathrm{Ile}_{321}$ bonds of prothrombin [31], converting it to mature thrombin, in contrast to group A and $B$ activators, which only convert prothrombin to meizothrombin. Recent structural studies indicate that the group $\mathrm{C}$ prothrombin activators structurally and functionally resemble the mammalian factor $\mathrm{Xa}-\mathrm{Va}$ complex.

\section{Group D Prothrombin Activators}

These are also serine proteinases found exclusively in the venoms of Australian elapids and their activities are strongly stimulated by $\mathrm{Ca}^{2+}$ ions, factor $\mathrm{Va}$ and negatively charged phospholipid vesicles [33-35]. They are serine proteinases with molecular mass ranging from 45,000 to 47,000 (based on mass spectrometry and primary structure [36], or from 52,000 to 58,000, SDS-PAGE, [37-41]). They have two chains held together by disulfide bonds. The serine proteinase active site is located in the heavy chain $[36,37]$.

They exhibit potent procoagulant effects, comparable to mammalian factor $\mathrm{Xa}$, through activation of prothrombin [36, 37]. Similar to factor Xa, they cleave prothrombin at two sites, $\operatorname{Arg}_{274}-\mathrm{Thr}_{275}$ and $\mathrm{Arg}_{323}-\mathrm{Ile}_{324}[36,37]$. Their poor activator activity is stimulated by more than a million-fold by negatively charged phospholipids, factor $\mathrm{Va}$ and $\mathrm{Ca}^{2+}$ ions [36, 37]. They also hydrolyze factor Xaspecific chromogenic substrates [36, 37]. Recently, we determined the complete amino acid sequences of trocarin [34] and hopsarin $\mathrm{D}$ [Rao et al., unpubl. data]. They share high identity (53-60\%) and homology (62-70\%) and hence similar domain architecture with factor Xa [36]. Their light chains are homologous to the light chains of vitamin K-dependent coagulation factors, especially that of factor Xa (53-59\% identity, 60-67\% homology with factor $\mathrm{Xa}$ ) [36]. Their light chains consist of an N-terminal Gla domain (residues 139), followed by two epidermal growth factor (EGF)-like domains, EGF-I (residues 50-81) and EGF-II (residues 89-124). Thus, group D venom prothrombin activators are true structural and functional homologues of blood coagulation factors.

\section{Thrombin-Like Enzymes}

These fibrinogen-clotting enzymes are widely distributed within several pit viper genera (Agkistrodon, Bothrops, Lachesis and Trimeresurus), as well as some true vipers (Bitis and Cerastes) and the colubrid, Dispholidus typus (for an inventory, see [42] and for recent review, see [43, 44]). The thrombinlike enzymes (TLEs) are single-chain serine proteinases (for example [45]), except for the enzyme from $C$. cerastes, which is reported to consist of two identical disulfide-linked chains [46]. Some of them are glycoproteins. They share a high degree of sequence identity among themselves (approximately 67\%). However, they show less than $40 \%$ homology with human thrombin. The presence of Asp 189 in all the TLEs explains their cleavage of 
arginyl bonds in fibrinogen, as this is the specificity pocket residue common to all serine proteinases that hydrolyze peptide bonds after basic residues [44]. They preferentially release either fibrinopeptide $\mathrm{A}$ or $\mathrm{B}$, rarely both with equal efficiency, unlike thrombin $[43,47]$. Secondary cleavages are also often seen. They also show a fair degree of species specificity in the efficiency of fibrinogen conversion. Classical serine proteinase inhibitors inhibit TLEs, but most of them are not inhibited by thrombin inhibitors like antithrombin III and hirudin [5, 43, 47]. They act on blood plasma usually forming friable and translucent clots, presumably due to a lack of crosslinking of fibrin by factor XIIIa. TLEs often act on coagulation factor XIII as well, but appear to degrade rather than activate it [5]. Unlike thrombin, TLEs do not activate other coagulation factors [47]. Thus, although TLEs 'resemble' thrombin to an extent, they are structurally and functionally dissimilar to the coagulation factor $[5,43,24]$. These unique properties enable their clinical use as defibrinogenating agents; for example, ancrod (Ar$\operatorname{vin}^{\circledR} ;$ Calloselasma rhodostoma) and batroxobin (Defibrase ${ }^{\circledR}$; B. atrox moojeni; [48]), [reviewed in ref. 43 and 49]. Since the fibrin formed is not cross-linked, it is readily degraded by the fibrinolytic system. TLEs are clinically well tolerated with no or only minimal side effects [43].

\section{Importance of Procoagulant Venom Proteins}

Procoagulant venom proteins activate the coagulation cascade at specific steps. This property has enabled their use in diagnosis of coagulation factor deficiencies by the determination of coagulation times of blood plasma treated with these proteins. As mentioned above, TLEs are also used for clinical defibrinogenation of blood plasma. The unique sequence specificity of cleavage of group D prothrombin activators can be exploited in cleavage of recombinant fusion proteins in molecular biology. Potentially, these proteins can also be used to selectively detect fully carboxylated prothrombin and lupus anticoagulant $[49,50]$ and possibly factor Va deficiency in human plasma. Finally, characterization of structure-function relationships in group $\mathrm{C}$ and $\mathrm{D}$ prothrombin activator will enable us to better understand interactions within the prothrombinase complex and the mechanisms of prothrombin activation.

\section{Acknowledgements}

This work was supported by National University of Singapore academic research grants R-154-000-093112 and R-368-000-004-112.

\section{References}

1 Kini RM, Chow G: Exogenous inhibitors of platelet aggregation from animal sources. Thromb Haemost 2001;85:179-181.

2 Chow G, Kini RM: Exogenous factors from animal sources that induce platelet aggregation. Thromb Haemost 2001;85:177-178.
3 Kini RM, Evans HJ: Effect of phospholipase $A_{2}$ enzymes on platelet aggregation; in Kini RM (ed): Venom Phospholipase $\mathrm{A}_{2}$ Enzymes: Structure, Function and Mechanism. Chichester, Wiley \& Sons, 1997, pp 369-387.

4 Kini RM, Evans HJ: Effects of snake venom proteins on blood platelets Toxicon 1990;28:1387-1422.
5 Hutton RA, Warrell DA: Action of snake venom components on the haemostatic system. Blood Rev 1993; 7:176-189.

6 Marsh NA: Snake venoms affecting the haemostatic mechanism - a consideration of their mechanisms, practical applications and biological significance. Blood Coagul Fibrinolysis 1994;5:399-410. 
7 Markland FS Jr: Snake venoms. Drugs 1997;54(suppl 3):1-10.

8 Tokunaga F, Iwanaga S: Proteases activating factor $\mathrm{V}$; in Bailey GS (ed): Enzymes from Snake Venom. Fort Collins, Alaken, 1998, pp 209225.

9 Rosing J, Govers-Riemslag JWP, Yukelson L, Tans G: Factor V activation and inactivation by venom proteases. Haemostasis 2001;31: 241-246.

10 Nakagaki T, Lin P, Kisiel W: Activation of human factor VII by the prothrombin activator from the venom of Oxyuranus scutellatus (Taipan snake). Thromb Res 1992;65: 105-116.

11 Morita T: Proteases which activate factor X; in Bailey GS (ed): Enzymes from Snake Venom. Fort Collins, Alaken, 1998, pp 179-208.

12 Tans G, Rosing J: Snake venom activators of factor $\mathrm{X}$ : An overview. Haemostasis 2001;31:225-233.

13 Williams WJ, Esnouf MP: The fractionation of Russell's viper (Vipera russelli) venom with special reference to the coagulant protein. Biochem J 1962;84:52-62.

14 Gowda DC, Davidson EA: Isolation and characterization of novel mucin-like glycoproteins from cobra venom. J Biol Chem 1994;269: 20031-20039.

15 Takeya H, Nishida S, Miyata T, Kawada S, Saisaka Y, Morita T, Iwanaga $S$ : Coagulation factor $X$ activating enzyme from Russell's viper venom (RVV-X). A novel metalloproteinase with disintegrin (platelet aggregation inhibitor)-like and C-type lectin-like domains. J Biol Chem 1992;267:14109-14117.

16 Atoda H, Hyuga M, Morita T: The primary structure of coagulation factor IX/factor X-binding protein isolated from the venom of Trimeresurus flavoviridis. Homology with asialoglycoprotein receptors, proteoglycan core protein, tetranectin, and lymphocyte Fce receptor for immunoglobulin E. J Biol Chem 1991; 266:14903-14911.

17 van Dieijen GV, Tans G, van Rijn JV, Zwaal RF, Rosing J: Simple and rapid method to determine the binding of blood clotting factor $\mathrm{X}$ to phospholipid vesicles. Biochemistry 1981;20:7096-7101.
18 Rosing J, Tans G: Inventory of exogenous prothrombin activators. Thromb Haemost 1991;65:627630.

19 Rosing J, Tans G: Structural and functional properties of snake venom prothrombin activators. Toxicon 1992;30:1515-1527.

20 Tans G, Rosing J: Prothrombin activation by snake venom proteases. $\mathrm{J}$ Toxicol Toxin Rev 1993;12:155173.

21 Petrovan R, Tans G, Rosing J: Proteases activating prothrombin; in Bailey GS (ed): Enzymes from Snake Venom. Fort Collins, Alaken, 1998, pp 227-252.

22 Kini RM, Morita T, Rosing J: Classification and nomenclature of prothrombin activators isolated from snake venoms. Thromb Haemost, in press.

23 Yamada D, Sekiya F, Morita T: Isolation and characterization of carinactivase, a novel prothrombin activator in Echis carinatus venom with a unique catalytic mechanism. J Biol Chem 1996;271:5200-5207.

24 Kini RM, Joseph JS and Rao VS: Prothrombin activators from snake venoms; in Mènez A (ed): Perspectives in Molecular Toxinology. Chichester, Wiley, in press.

25 Kornalik F, Blomback B: Prothrombin activation induced by Ecarin - a prothrombin converting enzyme from Echis carinatus venom. Thromb Res 1975;6:57-63.

26 Nishida S, Fujita T, Kohno N, Atoda H, Morita T, Takeya H, Kido I, Paine MJ, Kawabata S, Iwanaga S: cDNA cloning and deduced amino acid sequence of prothrombin activator (ecarin) from Kenyan Echis carinatus venom. Biochemistry 1995;34:1771-1778.

27 Yamada D, Morita T: Purification and characterization of a $\mathrm{Ca}^{2+}$ dependent prothrombin activator, multactivase, from the venom of Echis multisquamatus. J Biochem (Tokyo) 1997;122:991-997.

28 Yamada D, Morita T: CA-1 method, a novel assay for quantification of normal prothrombin using a $\mathrm{Ca}^{2+}$-dependent prothrombin activator, carinactivase- 1 . Thromb Res 1999;94:221-226.

29 Owen WG, Jackson CM: Activation of prothrombin with Oxyuranus scutellatus scutellatus (Taipan snake) venom. Thromb Res 1973;3:705714.

30 Walker FJ, Owen WG, Esmon CT: Characterization of the prothrombin activator from the venom of $O x$ yuranus scutellatus scutellatus (Taipan venom). Biochemistry 1980;19: 1020-1023.

31 Speijer H, Govers-Riemslag JWP, Zwaal RFA, Rosing J: Prothrombin activation by an activator from the venom of Oxyuranus scutellatus (Taipan snake). J Biol Chem 1986; 261:13258-13267.

32 Masci PP, Whitaker AN, de Jersey $\mathrm{J}$ : Purification and characterization of the prothrombin activator of the venom of Pseudonaja textilis; in Gopalakrishnakone $\mathrm{P}$, Tan $\mathrm{CK}$ (eds): Progress in Venom and Toxin Research. Proceedings of the First Asia-Pacific Congress on Animal, Plant and Microbial Toxins. Singapore, 1987, pp 209-219.

33 Jobin F, Esnouf MP: Coagulant activity of tiger snake (Notechis scutatus scutatus) venom. Nature 1966; 211:873-875.

34 Chester A, Crawford GP: In vitro coagulant properties of venoms from Australian snakes. Toxicon 1982;20:501-504.

35 Marshall LR, Herrmann RP: Coagulant and anticoagulant actions of Australian snake venoms. Thromb Haemost 1983;50:707-711.

36 Joseph JS, Chung MC, Jeyaseelan K, Kini RM: Amino acid sequence of trocarin, a prothrombin activator from Tropidechis carinatus venom: Its structural similarity to coagulation factor Xa. Blood 1999;94:621631.

37 Tans G, Govers-Riemslag JWP, van Rihn JL, Rosing J: Purification and properties of a prothrombin activator from the venom of Notechis scutatus scutatus. J Biol Chem 1985; 260:9366-9372.

38 Morrison JJ, Masci PP, Bennett EA, Gauci M, Pearn J. Whitaker AN, Korschenko LP: Studies of the venom and clinical features of the Australian rough-scaled snake (Tropidechis carinatus); in Gopalakrishnakone P, Tan CK (eds): Progress in Venom and Toxin Research. Proceedings of the First Asia-Pacific Congress on Animal, Plant and Microbial Toxins, Singapore, 1987, pp 220-233. 
39 Williams V, White J: Purification and properties of a procoagulant from peninsula tiger snake (Notechis ater niger) venom. Toxicon 1989; 27:773-779.

40 Stocker K, Hauer H, Muller C, Triplett DA: Isolation and characterization of Textarin, a prothrombin activator from eastern brown snake (Pseudonaja textilis) venom. Toxicon 1994;32:1227-1236.

41 Marsh NA, Fyffe TL, Bennett EA: Isolation and partial characterization of a prothrombin-activating enzyme from the venom of the Australian rough-scaled snake (Tropidechis carinatus). Toxicon 1997;35:563571.

42 Pirkle H, Stocker K: Thrombin-like enzymes from snake venoms: an inventory. Thromb Haemost 1991;65: 444-450.
43 Bell WR Jr: Defibrinogenating enzymes. Drugs 1997;54 (suppl 3):1830.

44 Pirkle H, Theodor I: Thrombin-like enzymes; in Bailey GS (ed): Enzymes from Snake Venom. Fort Collins, Alaken, 1998, pp 39-69.

45 Au LC, Lin SB, Chou JS, Teh GW, Chang KJ, Shih CM: Molecular cloning and sequence analysis of the cDNA for ancrod, a thrombin-like enzyme from the venom of Calloselasma rhodostoma. Biochem J 1993; 294:387-390.

46 Laraba-Djebari B, Martin-Eauclaire MF, Marchot P: A fibrinogen-clotting serine proteinase from Cerastes cerastes (horned viper) venom with arginine-esterase and amidase activities. Purification, characterization and kinetic parameter determination. Toxicon 1992;30:1399-1410.
47 Aronson DL: Comparison of the actions of thrombin and the thrombinlike venom enzymes ancrod and batroxobin. Thromb Haemost 1976; 36:9-13.

48 Stocker K, Barlow GH: The coagulant enzyme from Bothrops atrox venom (batroxobin). Methods Enzymol 1976;45:214-223.

49 Stocker K: Research, diagnostic and medicinal uses of snake venom enzymes; in Bailey GS (ed): Enzymes from Snake Venom. Fort Collins, Alaken, 1998, pp 705-736.

50 Triplett DA, Stocker KF, Unger GA, Barna LK: The Textarin/Ecarin ratio: A confirmatory test for lupus anticoagulants. Thromb Haemost 1993;70:925-931. 